Article

\title{
Development of Wood Composites from Recycled Fibres Bonded with Magnesium Lignosulfonate
}

\author{
Petar Antov ${ }^{1, *} \mathbb{B}$, George I. Mantanis ${ }^{2}$ and Viktor Savov ${ }^{1}$ \\ 1 Department of Mechanical Wood Technology, Faculty of Forest Industry, University of Forestry, \\ 1797 Sofia, Bulgaria; victor_savov@ltu.bg \\ 2 Department of Forestry, Wood Sciences and Design, Lab of Wood Science and Technology, University of \\ Thessaly, 43100 Karditsa, Greece; mantanis@uth.gr \\ * Correspondence: p.antov@ltu.bg
}

Received: 13 May 2020; Accepted: 25 May 2020; Published: 1 June 2020

\begin{abstract}
The potential of producing ecofriendly composites from industrial waste fibres, bonded with magnesium lignosulfonate, a lignin-based formaldehyde-free adhesive, was investigated in this work. Composites were produced in the laboratory using the following parameters: a hot press temperature of $210^{\circ} \mathrm{C}$, a pressing time of $16 \mathrm{~min}$, and a $15 \%$ gluing content of magnesium lignosulfonate (on the dry fibres). The physical and mechanical properties of the produced composites were evaluated and compared with the European Standard (EN) required properties (EN 312, EN 622-5) of common wood-based panels, such as particleboards for internal use in dry conditions (type P2), load-bearing particleboards for use in humid conditions (type P5), heavy-duty load-bearing particleboards for use in humid conditions (type P7), and medium-density fibreboards (MDF) for use in dry conditions. In general, the new produced composites exhibited satisfactory mechanical properties: a bending strength (MOR) $\left(18.5 \mathrm{~N} \cdot \mathrm{mm}^{-2}\right)$ that was $42 \%$ higher than that required for type P2 particleboards $\left(13 \mathrm{~N} \cdot \mathrm{mm}^{-2}\right)$ and $16 \%$ higher than that required for type P5 particleboards $\left(16 \mathrm{~N} \cdot \mathrm{mm}^{-2}\right)$. Additionally, the modulus of elasticity (MOE) of composites $\left(2225 \mathrm{~N} \cdot \mathrm{mm}^{-2}\right)$ was $24 \%$ higher than that required for type P2 particleboards $\left(1800 \mathrm{~N} \cdot \mathrm{mm}^{-2}\right)$ and equivalent to the required MOE of MDF panels for use in dry conditions $\left(2200 \mathrm{~N} \cdot \mathrm{mm}^{-2}\right)$. However, these ecofriendly composites showed deteriorated moisture properties, i.e., $24 \mathrm{~h}$ swelling and $24 \mathrm{~h}$ water absorption, which were a distinct disadvantage. This should be further investigated, as modifications in the lignosulfonate formula used and/or production parameters are necessary.
\end{abstract}

Keywords: wood composites; waste fibres; magnesium lignosulfonate; bioadhesives

\section{Introduction}

Optimisation of resource efficiency is one of the key objectives to implement the principles of circular economy and face the challenges of increased demand for wood and wood-based products worldwide. Cascading use of lignocellulosic resources, defined as "the efficient utilisation of resources by using residues and recycled materials for material use to extend total biomass availability within a given system", is one of the leading principles for achieving this goal [1,2]. Every year, pulp and paper industries generate significant quantities of nonhazardous solid waste and sludge, which require efficient utilisation as waste materials or by-products [3,4]. Pulp and paper sludge contains fibres and can therefore be re-used for the manufacturing of new composites [5-9].

Conventional adhesive systems used for wood composites are commonly made of fossil-derived constituents, which are based on formaldehyde, urea, phenol, melamine, and/or isocyanates [10-13]. Due to their high reactivity, chemical versatility, cost effectiveness, and technological performance regarding their strength of adhesion and moisture resistance, formaldehyde-based polycondensation 
adhesives have been widely used in wood-based panel industries [14-20]. Nonetheless, they have a major disadvantage, that is, their hazardous emission of volatile organic compounds (VOCs), such as formaldehyde, from finished panel products, especially in indoor environments [21,22]. In 2004, formaldehyde was reclassified from "probable human carcinogen" to "known human carcinogen" by the International Agency for Research on Cancer [23]. This, combined with increased environmental concerns, has changed the trend in the global wood industry from synthetic formaldehyde-based adhesives towards the development of biobased adhesives for the production of green composites [11-13,24-35]. This term, "green composites", refers to composites fabricated from both natural fibres and a biobased matrix [36,37]. Thus, such new wood composites, having acceptable physical and mechanical properties, can offer several important advantages, such as renewability, biodegradability, and lower production costs [26,32,33,38-43].

Following cellulose, lignin is the second most abundant polymer encountered in nature [44]. With an estimated 300 billion tons in the biosphere and an annual re-synthesis of ca. 20 billion tons [45,46], it is present in wood, grass, agricultural residues, and other plants [47]. In addition, lignin is considered as a valuable byproduct of the chemical pulping process of wood (i.e., lignosulfonates originating from the sulphite pulping process and kraft lignin from the sulphate pulping process), with an annual accumulation of more than 50-75 million tons worldwide [27,48,49]. Nevertheless, only $10 \%$ of technical lignin is further utilised industrially; the rest of it is mainly incinerated for energy purposes or remains unutilised [50-52]. Thus, lignin appears to be an abundant and renewable raw material for value-added chemicals [53], as well as for wood adhesives [12,13,26,32,54-61]. Due to its phenolic structure, lignin has favourable properties, such as high hydrophobicity and low polydispersity, for the formulation of new adhesives suitable for the wood-based panel industry [62]. However, the aromatic structure of lignin lowers the reactivity of the resin, which represents a significant drawback in applications where fast-curing times are needed.

Lignosulfonates (R-SO3H), the salts of lignin sulfonic acid, are one of the main sources of technical lignins. They are water-soluble anionic polyelectrolytes obtained as the byproducts of the sulphite process in which delignification of wood is performed by means of $\mathrm{HSO}_{3}{ }^{-}$and $\mathrm{SO}_{3}{ }^{2-}$ ions $[63,64]$. Lignosulfonates derived from sulphite lignin processing have a relatively high molecular weight $\left(15,000-50,000 \mathrm{~g} \cdot \mathrm{mol}^{-1}\right)$, a high content of inorganics (up to $25 \%$ ), and a sulphur content of approx. $8 \%$ [49,65]. Lignosulfonates are produced as dry solids in relatively large quantities, e.g., the annual production is approximately 1.1 million tons [66,67]. Increased scientific and industrial interest in lignin-originating compounds, including lignosulfonates, is due to the phenolic structure of lignin allowing partial replacement of phenol $\left(\mathrm{C}_{6} \mathrm{H}_{6} \mathrm{O}\right)$ in the formulation of lignin-phenol-formaldehyde (LPF) resins to formulate adhesives for wood products [12,28,68-71], in order to decrease production costs and reduce toxicity. The use of unpurified sulphur-containing lignosulfonates results in lower reactivity of the resin, leading to extended pressing times [72,73]. In order to use lignosulfonates as main components of adhesives, this lower reactivity should be compensated by a suitable cross-linker [26] or by modifying the parameters for the production of new composites [74,75].

The aim of this research work was to investigate the potential of producing ecofriendly composites from waste wood fibres, bonded with a lignin-based adhesive, namely, magnesium lignosulfonate, complying with the requirements of the European Standards.

\section{Materials and Methods}

Industrial waste fibre mass (Figure 1) composed of two softwood species, namely, Scots pine (Pinus silvestris L.) and Norway spruce (Picea abies Karst.), oven dried to $12 \%$ moisture content, was supplied by the company Mondi Stambolyiski EAD, a Bulgarian paper mill (Stambolyiski, Bulgaria). The bulk density of it was $4468 \mathrm{~kg} \cdot \mathrm{m}^{-3}$. The main fibre fraction appeared to have a length between 500 and $1000 \mu \mathrm{m}$ and a reduced lignin content of $7 \%$. 


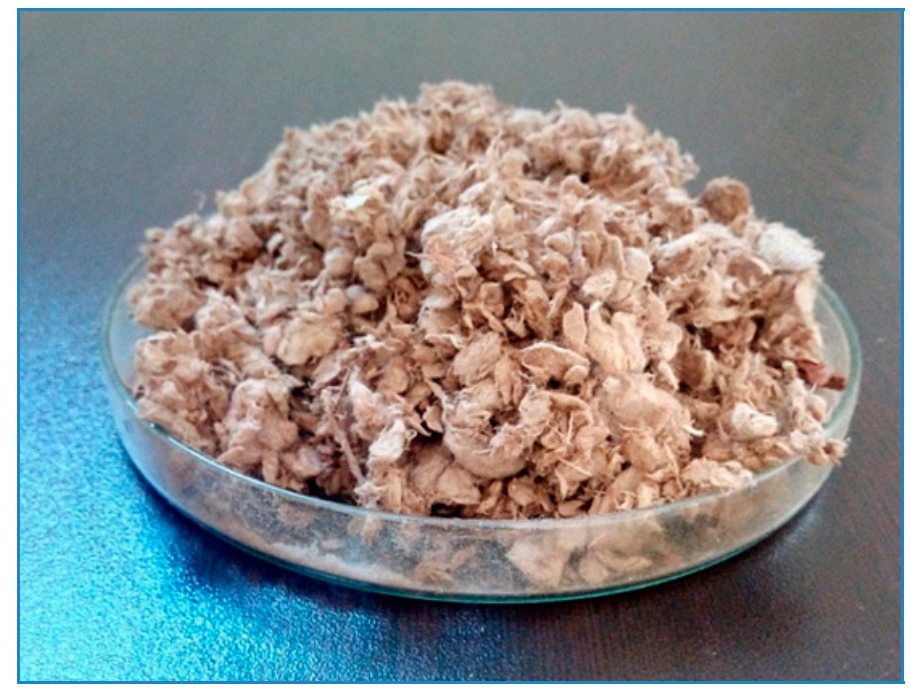

Figure 1. Industrial waste fibre mass (photo by V. Savov).

Magnesium lignosulfonate additive (CAS No. 8061-54-9), which is named Borresperse 390 Paper (Borregaard, Germany), was utilised as a main binder at 15\% gluing content on the dry weight of the fibres. This additive had the following characteristics: magnesium content: $6 \%$; reduced sugars: $7 \%$; sulphate content: $2 \%$; and total solids content: $51.2 \%$. European beech (Fagus sylvatica L.) veneer sheets, having a thickness of $1.1 \mathrm{~mm}$ and a moisture content of approximately $8 \%$, provided by the company Welde Bulgaria AD (Troyan, Bulgaria), were used for veneering the surface layers of the composites.

Firstly, fibreboards were produced in the laboratory at a thickness of $16 \mathrm{~mm}$ and a target density of $720 \mathrm{~kg} \cdot \mathrm{m}^{-3}$. Industrial waste fibres were mixed with the lignosulfonate-based adhesive in a high-speed laboratory glue blender $\left(850 \mathrm{~min}^{-1}\right)$. Hot pressing was performed in a laboratory press (PMC ST 100 , Italy). The press temperature used was $210^{\circ} \mathrm{C}$. The pressing regime applied consisted of the following four stages: In the first stage, the pressure was increased to $4.5 \mathrm{MPa}$ for $1 \mathrm{~min}$, then, it was gradually decreased to $2.23 \mathrm{MPa}$ for $3 \mathrm{~min}$, followed by decreasing the pressure to $0.74 \mathrm{MPa}$ for $10 \mathrm{~min}$. The last pressing period was implemented at a pressure of $1.78 \mathrm{MPa}$ for $2 \mathrm{~min}$. Following hot pressing, the produced fibreboards were conditioned in a laboratory acclimatising chamber at $20^{\circ} \mathrm{C}$ and $60 \%$ relative humidity, for a period of 7 days.

After that, the fibreboards were veneered with beech veneer sheets, using magnesium lignosulfonate as a binder, at a gluing content of $80 \mathrm{~g} / \mathrm{m}^{2}$. The applied veneering press factor was $1 \mathrm{~min} \mathrm{~mm} \mathrm{~m}^{-1}$ of panel thickness, at a pressure of $0.6 \mathrm{MPa}$ and a press temperature of $200{ }^{\circ} \mathrm{C}$.

The physical and mechanical properties of the new composites were determined according to the European Standards EN 310, EN 317, EN 322, and EN 323 [76-79]. Thickness swelling and water absorption tests were carried out for $24 \mathrm{~h}$. Precision balance (Kern, Germany) with a readability of $0.01 \mathrm{~g}$ and a digital calliper with a readability of $0.01 \mathrm{~g}$ were used to determine the mass and dimensions of the test specimens, respectively. For measurement of the mechanical properties of the composites, a universal-material testing machine Zwick/Roell Z010 was used.

Formaldehyde emission of the fabricated composites was measured in the laboratory of the factory Kronospan Bulgaria EOOD (Veliko Tarnovo, Bulgaria) on four samples using the perforator method [80].

In the last part, variational and statistical analysis of the results was performed with the specialised software QstatLab 6.0. 


\section{Results and Discussion}

\subsection{Formaldehyde Emission}

The formaldehyde emission of the produced composites was estimated to be $1.1 \mathrm{mg} / 100 \mathrm{~g}( \pm 0.1)$, according to the standard EN ISO (International Organization for Standardization) 12460-5 (2015). This emission value is exceptionally low and is considered as a zero formaldehyde value [13,80]. Formaldehyde is a naturally occurring compound in wood, formed by its main polymeric components (i.e., cellulose, hemicellulose, and lignin) or extractives [81,82]. Thus, the determined formaldehyde emission value, which is much lower than $2 \mathrm{mg} / 100 \mathrm{~g}$, i.e., the emission of natural wood [13,26], allows for the defining of fabricated composites as ecofriendly composites.

\subsection{Physical and Mechanical Properties}

A summary of the physical and mechanical properties of the composites, comprising recycled wood fibres and magnesium lignosulfonate, is shown in Table 1. The respective variational and statistical data are also presented. The density of the composites varied from 681 to $772 \mathrm{~kg} \cdot \mathrm{m}^{-3}$, relatively close to the projected value. The difference in this main characteristic of the composites was significantly below 5\%; thus, this will not have an effect on the other physical and mechanical properties.

Table 1. Physical and mechanical properties of the laboratory-produced composites.

\begin{tabular}{|c|c|c|c|c|c|}
\hline Property & $\begin{array}{l}\text { Average (Mean } \\
\text { Value) } \bar{X}\end{array}$ & $\begin{array}{c}\text { Standard } \\
\text { Deviation } S_{x}\end{array}$ & $\begin{array}{l}\text { Standard Error } \\
\qquad m_{x}\end{array}$ & $\begin{array}{c}\text { Probability } \\
\left(p \text {-Value) } P_{x}, \%\right.\end{array}$ & $\begin{array}{l}\text { Sample } \\
\text { Size }\end{array}$ \\
\hline Density $\rho, \mathrm{kg} \cdot \mathrm{m}^{-3}$ & 743 & 23.9 & 7.5 & 1.0 & 10 \\
\hline $\begin{array}{l}\text { Water absorption } \\
\text { (24 h) } A, \%\end{array}$ & 168.4 & 12.9 & 4.1 & 2.4 & 10 \\
\hline $\begin{array}{l}\text { Thickness swelling } \\
\text { (24 h) Gt, \% }\end{array}$ & 82.8 & 5.9 & 1.9 & 2.3 & 10 \\
\hline $\begin{array}{l}\text { Bending strength } \\
(\mathrm{MOR}) \mathrm{fm}, \mathrm{N} \cdot \mathrm{mm}^{-2}\end{array}$ & 18.5 & 1.6 & 0.6 & 3.1 & 8 \\
\hline $\begin{array}{c}\text { Modulus of } \\
\text { elasticity }(\mathrm{MOE}) \\
E m, \mathrm{~N} \cdot \mathrm{mm}^{-2}\end{array}$ & 2255 & 228 & 81 & 3.6 & 8 \\
\hline
\end{tabular}

In order to analyse the technical properties of the produced composites, which were fabricated from recycled lignocellulosic fibres, bonded with magnesium lignosulfonate, and veneered with beech veneers (experimental boards; labelled as Eb), their physical and mechanical properties were compared with the minimum required properties of common wood-based panels, such as (i) particleboards for internal use (including furniture) in dry conditions (type P2), (ii) load-bearing particleboards for use in humid conditions (type P5), (iii) heavy-duty load-bearing particleboards for use in humid conditions (type P7) [83], and (iv) medium-density fibreboards (MDF) for use in dry conditions [84]. Particleboards of type P2 and MDF were selected, since they are the most commonly used panels. Particleboards of types P5 and P7 were selected because of the very stringent requirements in respect of their mechanical and swelling properties.

As is known in the art [10,11,13], water absorption (WA) and thickness swelling (TS) are critical physical properties, strongly related with the dimensional stability of wood-based composites. WA is not a standardised technical property; nonetheless, according to the literature [85], the WA of common MDF typically varies between $50 \%$ and $70 \%$. In this work, the WA of the laboratory-fabricated composites was found to be approximately $168 \%$, i.e., three times higher than that of a standard-grade MDF panel. Consequently, magnesium lignosulfonate, as a lignin-based compound, will require a chemical modification, among others, in order to increase its chemical reactivity and bonding efficiency $[49,70]$. 
A graphical representation of the TS of the compared wood-based composites is presented in Figure 2. The particleboard for internal use (type P2) is not included, as the thickness swelling limit is not required by the standard EN 312 (2010).

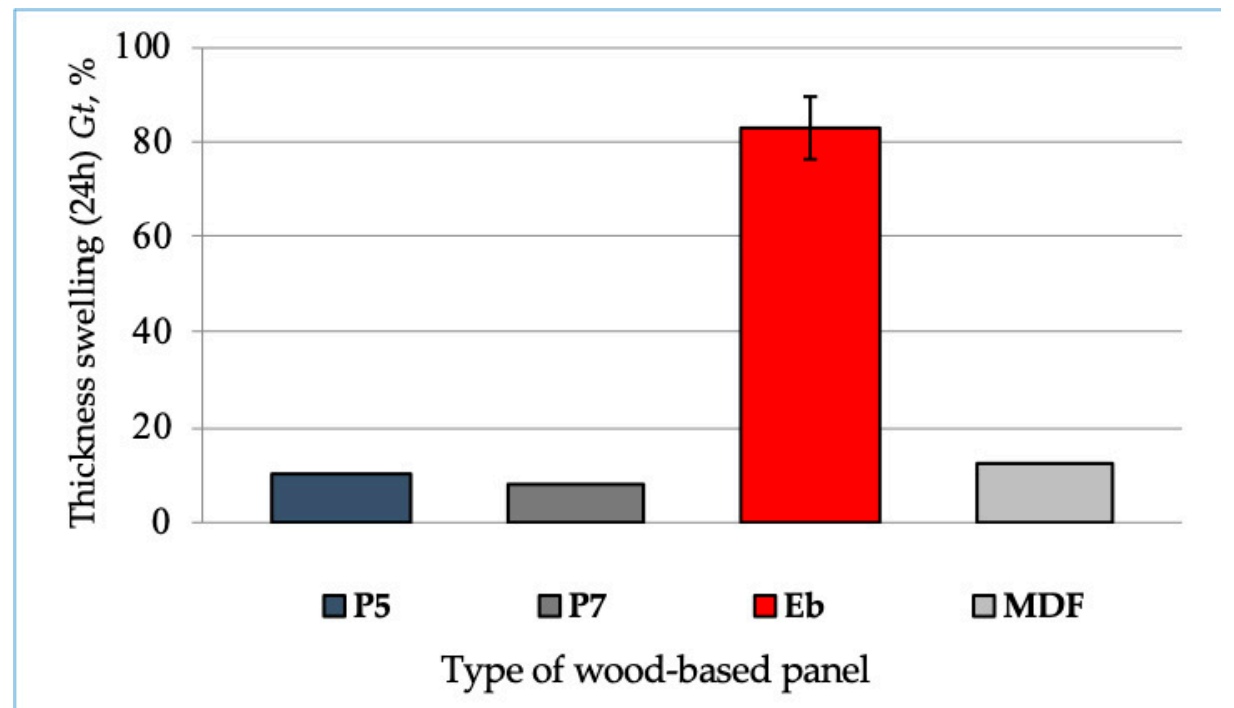

Figure 2. Thickness swelling of composites produced (experimental board: Eb). (Error bar represents the standard deviation.)

As seen in Figure 2, the composite Eb exhibited very high swelling values, i.e., 6 times higher than the minimum limit of MDF for use in dry conditions, 7 times higher than the minimum limit of load-bearing particleboards for use in humid conditions (type P5), and 9 times higher than the minimum limit of heavy-duty load-bearing particleboards for use in humid conditions (type P7).

In addition, a graphical representation of the mean bending strength (MOR) of composite Eb and the minimum required MOR limit values of typical wood-based panels is shown in Figure 3.

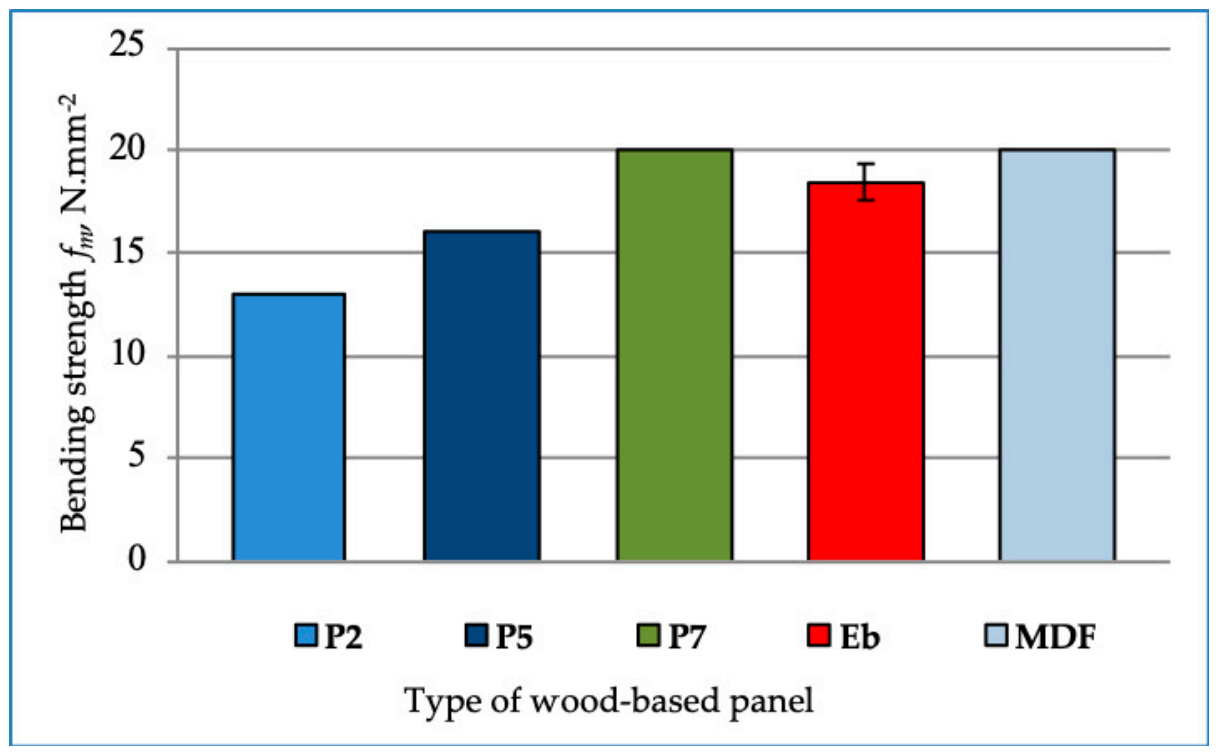

Figure 3. Bending strength (MOR) of the produced composite panels vs. MOR limit values of typical wood-based panels. (Error bar represents the standard deviation.)

The produced ecofriendly composite Eb exhibited very satisfactory bending strength properties, i.e., the MOR was $42 \%$ higher than the minimum required MOR value of particleboards for interior fitments 
(type P2; $13 \mathrm{~N} \cdot \mathrm{mm}^{-2}$ ). Composite $\mathrm{Eb}$ showed higher MOR values as compared with the minimum accepted MOR for load-bearing particleboards for use in humid conditions (type P5; $16 \mathrm{~N} \cdot \mathrm{mm}^{-2}$ ). Furthermore, ecofriendly composite Eb exhibited a mean MOR strength of $18.5 \mathrm{~N} \cdot \mathrm{mm}^{-2}$, which was slightly lower than the minimum MOR limit for MDF panels (i.e., $20 \mathrm{~N} \cdot \mathrm{mm}^{-2}$ ) and the minimum MOR for heavy-duty load-bearing particleboards for use in humid conditions (type P7; $20 \mathrm{~N} \cdot \mathrm{mm}^{-2}$ ). Thus, these MOR values were quite comparable. It should be noted that, typically, P7-type particleboards are heavy or very heavy wood panels, while the composite Eb produced in this work had significantly lower densities.

Finally, a graphical representation of the average modulus of elasticity (MOE) of composite Eb and the minimum required MOE limit values of selected wood-based panels is shown in Figure 4.

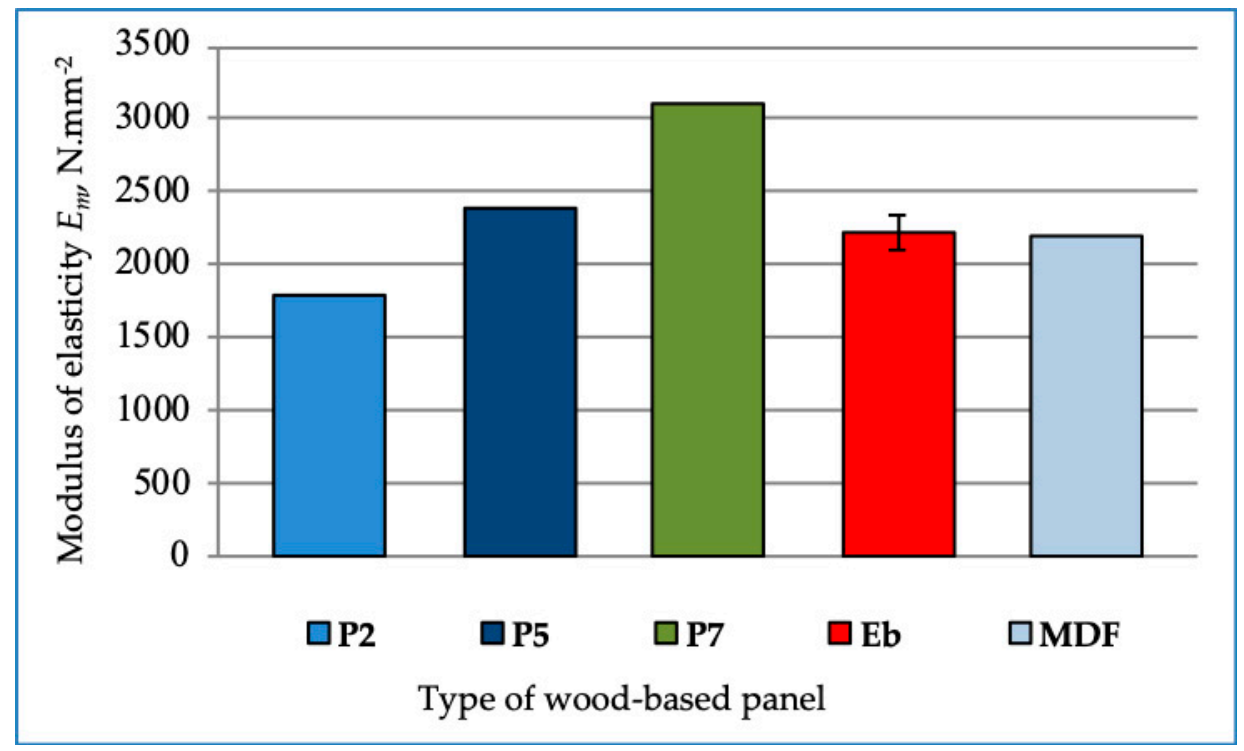

Figure 4. Modulus of elasticity (MOE) of the produced composite panels vs. MOE limit values of typical wood-based panels. (Error bar represents the standard deviation.)

The mean MOE of the composite Eb was found to be ca. $2225 \mathrm{~N} \cdot \mathrm{mm}^{-2}$. This value is $24 \%$ larger than the minimum accepted for particleboards for interior fitments for use in dry conditions (type $\mathrm{P} 2 ; 1800 \mathrm{~N} \cdot \mathrm{mm}^{-2}$ ) and almost equivalent to the MOE limit value of MDF for use in dry conditions $\left(2200 \mathrm{~N} \cdot \mathrm{mm}^{-2}\right)$. The composite Eb showed a lower MOE property as compared with the minimum MOE limit of load-bearing particleboards for use in humid conditions (type P5; $2400 \mathrm{~N} \cdot \mathrm{mm}^{-2}$ ) and heavy-duty load-bearing particleboards for use in humid conditions (type P7; $3100 \mathrm{~N} \cdot \mathrm{mm}^{-2}$ ). Laboratory-made composites cannot be utilised for load-bearing applications, in which quite an increased load resistance is needed. As a whole, it is a positive outcome that developed ecofriendly composites exhibited much higher strength properties than the minimum required for particleboards for interior fitments, including furniture (type P2), and similar strength properties as compared to common MDF boards.

\section{Conclusions}

Ecofriendly composites with acceptable physical and mechanical properties according to ENs, except for thickness swelling, may be produced from industrial waste fibres, bonded with a lignin-based formaldehyde-free adhesive, namely, magnesium lignosulfonate. The composites were manufactured in the laboratory using 15\% gluing content of magnesium lignosulfonate as a binder, following the covering of composites with beech veneers, also glued with magnesium lignosulfonate. As above, laboratory-fabricated composites showed quite satisfactory mechanical properties, such as MOR and $\mathrm{MOE}$, which were higher than the minimum required for particleboards for interior fitments for use in dry conditions (type P2) and equivalent to the least required for MDF panels of standard grade. 
Markedly, the produced ecofriendly composites had "almost zero" emission of formaldehyde (ca. $1.1 \mathrm{mg}$ per $100 \mathrm{~g}$ of composite), as measured by the standard perforator method.

Nonetheless, the produced composites exhibited a deteriorated dimensional stability, as found in panel properties like thickness swelling and water absorption $(24 \mathrm{~h})$, which was a major drawback; this disadvantage could be resolved by modifications of the lignosulfonate formula. Therefore, future research should focus on optimising the production and pressing parameters, as well as further investigating the bonding mechanism between lignosulfonate and fibres.

Nevertheless, new ecofriendly composites represent promising alternatives to conventional wood-based panels, which utilise only petroleum-derived adhesives. As this research showed, waste fibres from the pulp and paper industries, as raw materials, can be efficiently utilised, and industrial waste discharge can be reduced, thus contributing to the implementation of circular economy principles.

Author Contributions: Conceptualisation, P.A. and V.S.; methodology, P.A. and V.S.; validation, P.A. and G.I.M.; investigation, P.A., G.I.M., and V.S.; resources, P.A. and V.S.; writing the original draft preparation, P.A. and G.I.M.; Writing-review and editing, G.I.M. and P.A.; visualisation, P.A. and V.S.; supervision, P.A. and G.I.M.; project administration, P.A. All authors have read and agreed to the published version of the manuscript.

Funding: This research work was supported by project no. НИС-Б-1002/03.2019 “Exploitation Properties and Possibilities for Utilisation of Eco-friendly Bio-composite Materials", which was carried out at the facilities of the University of Forestry (Sofia, Bulgaria), in cooperation with the University of Thessaly (Department of Forestry, Wood Sciences and Design, Karditsa, Greece).

Conflicts of Interest: The authors declare no conflict of interest.

\section{References}

1. Stevulova, N.; Schwarzova, I.; Hospodarova, V.; Junak, J.; Briancin, J. Recycled cellulosic fibres and lignocellulosic aggregates from sustainable building materials. IJCEE 2016, 10, 716-721.

2. Vis, M.; Mantau, U.; Allen, B. (Eds.) Study on the Optimised Cascading Use of Wood, No 394/PP/ENT/RCH/14/7689, Final Report; Publications Office: Brussels, Belgium, 2016; p. 337.

3. Ochoa de Alda, J.A.G. Feasibility of recycling pulp and pulp and paper sludge in the paper and board industries. Resour. Conserv. Recycl. 2008, 52, 965-972. [CrossRef]

4. Bajpai, P. Generation of Waste in Pulp and Paper Mills. In Management of Pulp and Paper Mill Waste; Springer: Berlin/Heidelberg, Germany, 2015; ISBN 978-3-319-11788-1.

5. Davis, E.; Shaler, S.M.; Goodell, B. The incorporation of paper deinking sludge into fibreboard. For. Prod. J. 2003, 53, 46-54.

6. Geng, X.; Deng, J.; Zhang, S.Y. Pulp and paper sludge as a component of wood adhesive formulation. Holzforschung 2007, 61, 688-692. [CrossRef]

7. Geng, X.; Deng, J.; Zhang, S.Y. Characteristics of pulp and paper sludge and its utilization for the manufacture of medium density fibreboard. Wood Fiber Sci. 2007, 39, 345-351.

8. Migneault, S.; Koubaa, A.; Nadji, H.; Riedl, B.; Zhang, S.Y.; Deng, J. Medium-density fibreboard produced using pulp and paper sludge from different pulping processes. Wood Fiber Sci. 2010, 42, 292-303.

9. Antov, P.; Savov, V. Possibilities for manufacturing eco-friendly medium density fibreboards from recycled fibres-A review. In Proceedings of the 30th International Conference on Wood Science and Technology-ICWST 2019 "Implementation of wood science in woodworking sector" and 70th anniversary of Drvna industrija Journal, Zagreb, Croatia, 12-13 December 2019; ISBN 978-953-292-062-8.

10. Youngquist, J.A. Wood-based composites and panel products. In Wood Handbook: Wood as an Engineering Material; USDA Forest Service, Forest Products Laboratory: Madison, WI, USA, 1999; pp. 1-31.

11. Frihart, C.R. Wood adhesion and adhesives. In Handbook of Wood Chemistry and Wood Composites; Rowell, R.M., Ed.; CRC Press: Boca Raton, FL, USA, 2005; pp. 214-278.

12. Ferdosian, F.; Pan, Z.; Gao, G.; Zhao, B. Bio-based adhesives and evaluation for wood composites application. Polymers 2017, 9, 70. [CrossRef]

13. Mantanis, G.I.; Athanassiadou, E.T.; Barbu, M.C.; Wijnendaele, K. Adhesive systems used in the European particleboard, MDF and OSB industries. Wood Mater. Sci. Eng. 2018, 13, 104-116. [CrossRef]

14. He, G.; Yan, N. Effect of moisture content on curing kinetics of pMDI resin and wood mixtures. Int. J. Adhes. Adhes. 2005, 25, 450-455. [CrossRef] 
15. Jin, Y.; Cheng, X.; Zheng, Z. Preparation and characterization of phenol-formaldehyde adhesives modified with enzymatic hydrolysis lignin. Bioresour. Technol. 2010, 101, 2046-2048. [CrossRef]

16. Zhang, W.; Ma, Y.; Wang, C.; Li, S.; Zhang, M.; Chu, F. Preparation and properties of lignin-phenolformaldehyde resins based on different biorefinery residues of agricultural biomass. Ind. Crops Prod. 2013, 43, 326-333. [CrossRef]

17. Jivkov, V.; Simeonova, R.; Marinova, A. Influence of the veneer quality and load direction on the strength properties of beech plywood as structural material for furniture. Innov. Woodwork. Ind. Eng. Des. 2013, 2, 86-92.

18. Jivkov, V.; Simeonova, R.; Marinova, A.; Gradeva, G. Study on the gluing abilities of solid surface composites with different wood based materials and foamed PVC. In Proceedings of the 24th International Scientific Conference Wood is Good-User Oriented Material, Technology and Design, Zagreb, Croatia, 18 October 2013; pp. 49-55, ISBN 978-953-292-031-4.

19. Yang, S.; Zhang, Y.; Yuan, T.Q.; Sun, R.C. Lignin-phenol-formaldehyde resin adhesives prepared with biorefinery technical lignins. J. Appl. Polym. Sci. 2015, 132, 42493. [CrossRef]

20. Solt, P.; Konnerth, J.; Gindl-Altmutter, W.; Kantner, W.; Moser, J.; Mitter, R.; Van Herwijnen, H. Technological performance of formaldehyde-free adhesive alternatives for particleboard industry. Int. J. Adhes. Adhes. 2019, 94, 99-131. [CrossRef]

21. Kelly, T.J. Determination of Formaldehyde and Toluene Diisocyanate Emissions from Indoor Residential Sources (No. 97-9); California Environmental Protection Agency: Sacramento, CA, USA, 1997.

22. U.S. Consumer Product Safety Commission. An Update on Formaldehyde (Publication 725); U.S. Consumer Product Safety Commission: Bethesda, MD, USA, 2013.

23. International Agency for Research on Cancer. IARC Classifies Formaldehyde as Carcinogenic to Humans; IARC: Lyon, France, 2004.

24. Dunky, M. Adhesives based on formaldehyde condensation resins. Macromol. Symp. 2004, 217, 417-429. [CrossRef]

25. Widyorini, R.; Xu, J.; Umemura, K.; Kawai, S. Manufacture and properties of binderless particleboard from bagasse I: Effects of raw material type, storage methods, and manufacturing process. J. Wood Sci. 2005, 51, 648-654. [CrossRef]

26. Pizzi, A. Recent developments in eco-efficient bio-based adhesives for wood bonding: Opportunities and issues. J. Adhes. Sci. Technol. 2006, 20, 829-846. [CrossRef]

27. Kües, U. Wood Production, Wood technology, and Biotechnological Impacts; Universitätsverlag Göttingen: Göttingen, Germany, 2007. Available online: https://univerlag.uni-goettingen.de/handle/3/isbn-978-3-940344-11-3 (accessed on 28 February 2020).

28. Papadopoulou, E. Adhesives from renewable resources for binding wood-based panels. J. Environ. Prot. Ecol. 2009, 10, 1128-1136.

29. Navarrete, P.; Mansouri, H.R.; Pizzi, A.; Tapin-Lingua, S.; Benjelloun-Mlayah, B.; Pasch, H. Wood panel adhesives from low molecular mass lignin and tannin without synthetic resins. J. Adhes. Sci. Technol. 2010, 24, 1597-1610. [CrossRef]

30. Carvalho, L.; Magalhães, F.; João, F. Formaldehyde emissions from wood-based panels-Testing methods and industrial perspectives. In Formaldehyde: Chemistry, Applications and Role in Polymerization; Chan, B.C., Feng, H.L., Eds.; Nova Science Publishers, Inc.: Hauppauge, NY, USA, 2012; pp. 1-45.

31. Vnučec, D.; Kutnar, A.; Goršek, A. Soy-based adhesives for wood-bonding-A review. J. Adhes. Sci. Technol. 2016, 31, 910-931. [CrossRef]

32. Hemmilä, V.; Adamopoulos, S.; Karlsson, O.; Kumar, A. Development of sustainable bio-adhesives for engineered wood panels-A review. RSC Adv. 2017, 7, 38604-38630. [CrossRef]

33. Nordström, E.; Demircan, D.; Fogelström, L.; Khabbaz, F.; Malmström, E. Green binders for wood adhesives. In Applied Adhesive Bonding in Science and Technology; Interhopen Books: London, UK, 2017; pp. 47-71. [CrossRef]

34. Valyova, M.; Ivanova, Y.; Koynov, D. Investigation of free formaldehyde quantity in production of plywood with modified urea-formaldehyde resin. Int. J. Wood Des. Technol. 2017, 6, 72-76.

35. Taghiyari, H.R.; Tajvidi, M.; Taghiyari, R.; Mantanis, G.I.; Esmailpour, A.; Hosseinpourpia, R. Nanotechnology for wood quality improvement and protection. In Nanomaterials for Agriculture and Forestry Applications; Husen, A., Jawaid, M., Eds.; Elsevier: Amsterdam, The Netherlands, 2020; pp. 469-489. 
36. Pfister, D.P.; Larock, R.C. Green composites using switchgrass as a reinforcement for a conjugated linseed oil-based resin. J. Appl. Polym. Sci. 2013, 127, 1921-1928. [CrossRef]

37. Yuan, Y.; Guo, M.; Liu, F. Preparation and evaluation of green composites using modified ammonium lignosulfonate and polyethylenimine as a binder. BioResources 2014, 9, 836-848. [CrossRef]

38. El Mansouri, N.E.; Pizzi, A.; Salvado, J. Lignin-based wood panel adhesives without formaldehyde. Holz. Roh. Werkst. 2007, 65, 65-70. [CrossRef]

39. Nasir, M.; Gupta, A.; Beg, M.; Chua, G.K.; Kumar, A. Physical and mechanical properties of medium density fibreboard using soy-lignin adhesives. J. Trop For. Sci. 2014, 1, 41-49.

40. Papadopoulou, E.; Kountouras, S.; Chrissafis, K.; Kirpluks, M.; Cabulis, U.; Šviglerova, P.; Benjelloun-Mlayah, B. Evaluation of the particle size of organosolv lignin in the synthesis of resol resins for plywood and their performance on fire spreading. TAPPI J. 2017, 16, 409-416. [CrossRef]

41. Sepahvand, S.; Doosthosseini, K.; Pirayesh, H.; Maryan, B.K. Supplementation of natural tannins as an alternative to formaldehyde in urea and melamine formaldehyde resins used in MDF production. Drv. Ind. 2018, 69, 215-221. [CrossRef]

42. Hosseinpourpia, R.; Adamopoulos, S.; Mai, C.; Taghiyari, H.R. Properties of medium-density fibreboards bonded with dextrin-based wood adhesives. Wood Res. 2019, 64, 185-194.

43. Tisserat, B.; Eller, F.; Mankowski, E. Properties of composite wood panels fabricated from Eastern red cedar employing various bio-based green adhesives. BioResources 2019, 14, 6666-6685.

44. Lora, J.H.; Glasser, W.G. Recent industrial applications of lignin: A sustainable alternative to nonrenewable materials. J. Polym. Environ. 2002, 10, 39-48. [CrossRef]

45. Glasser, W.G.; Kelly, S.S. Lignin. In Encyclopedia of Polymer Science and Engineering, 2nd ed.; Mark, H.F., Bikales, N., Overberger, C.G., Menges, G., Kroschwitz, J.I., Eds.; Wiley: New York, NY, USA, 1987; pp. $795-852$.

46. Argyropoulos, D.S.; Menachem, S.B.; Eriksson, K.E.L.; Babel, W.; Blanch, H.W.; Cooney, C.L.; Enfors, S.O.; Eriksson, K.E.L. (Eds.) Biotechnology in the Pulp and Paper Industry; Springer: Berlin/Heidelberg, Germany, 1997; pp. 127-158.

47. Fu, D.; Mazza, G.; Tamaki, Y. Lignin extraction from straw by ionic liquids and enzymatic hydrolysis of the cellulosic residues. J. Agric. Food Chem. 2010, 58, 2915-2922. [CrossRef] [PubMed]

48. Pizzi, A. Bioadhesives for wood and fibres. Rev. Adhes. Adhes. 2013, 1, 88-113. [CrossRef]

49. Laurichesse, S.; Avérous, L. Chemical modification of lignins: Towards biobased polymers. Prog. Polym. Sci. 2014, 39, 1266-1290. [CrossRef]

50. Chakar, F.S.; Ragauskas, A.J. Review of current and future softwood kraft lignin process chemistry. Ind. Crops Prod. 2004, 20, 131-141. [CrossRef]

51. Gargulak, J.D.; Lebo, S.E. Commercial use of lignin-based materials. In Lignin: Historical, Biological, and Material Perspectives; Glasser, W.G., Northey, R.A., Schultz, T.P., Eds.; American Chemical Society: Washington, DC, USA, 2000; pp. 304-320.

52. Waldron, K. Advances in Biorefineries: Biomass and Waste Supply Chain Exploitation; Woodhead Publishing: London, UK, 2014.

53. Vanholme, R.; Demedts, B.; Morreel, K.; Ralph, J.; Boerjan, W. Lignin biosynthesis and structure. Plant. Physiol. 2016, 153, 895-905. [CrossRef]

54. Geng, X.; Li, K. Investigation of wood adhesives from kraft lignin and polyethylenimine. J. Adhes. Sci. Technol. 2006, 20, 847-858. [CrossRef]

55. Mancera, C.; El Mansouri, N.E.; Vilaseca, F.; Ferrando, F.; Salvado, J. The effect of lignin as a natural adhesive on the physico-mechanical properties of Vitis vinifera fibreboards. BioResources 2011, 6, 2851-2860.

56. Ghaffar, S.H.; Fan, M. Lignin in straw and its applications as an adhesive. Int. J. Adhes. Adhes. 2014, 48, 92-101. [CrossRef]

57. Yotov, N.; Valchev, I.; Petrin, S.; Savov, V. Lignosulphonate and waste technical hydrolysis lignin as adhesives for eco-friendly fibreboard. Bulg. Chem. Commun. 2017, 49, 92-97.

58. Klapiszewski, Ł.; Jamrozik, A.; Strzemiecka, B.; Voelkel, A.; Jesionowski, T. Activation of magnesium lignosulfonate and kraft lignin: Influence on the properties of phenolic resin-based composites for potential applications in abrasive materials. Int. J. Mol. Sci. 2017, 18, 1224. [CrossRef] [PubMed]

59. Klapiszewski, Ł.; Oliwa, R.; Oleksy, M.; Jesionowski, T. Calcium lignosulfonate as eco-friendly additive of crosslinking fibrous composites with phenol-formaldehyde resin matrix. Polymers 2018, 63, 102-108. [CrossRef] 
60. Hazwan Hussin, M.; Aziz, A.A.; Iqbal, A.; Ibrahim, M.; Latif, N. Development and characterization novel bio-adhesive for wood using kenaf core (Hibiscus cannabinus) lignin and glyoxal. Int. J. Biol. Macromol. 2019, 122, 713-722. [CrossRef] [PubMed]

61. Zhang, J.; Wang, W.; Zhou, X.; Liang, J.; Du, G.; Wu, Z. Lignin-based adhesive cross-linked by furfuryl alcohol-glyoxal and epoxy resins. Nord. Pulp. Paper Res. J. 2019, 34, 228-238. [CrossRef]

62. Vázquez, G.; González, J.; Freire, S.; Antorrena, G. Effect of chemical modification of lignin on the gluebond performance of lignin-phenolic resins. Biores. Technol. 1997, 60, 191-198. [CrossRef]

63. Fan, J.; Zhan, H. Optimization of synthesis of spherical lignosulphonate resin and its structure characterization. Chin. J. Chem. Eng. 2008, 16, 407-410. [CrossRef]

64. Vishtal, A.; Kraslawski, A. Challenges in industrial applications of technical lignins. BioResources 2011, 6, 3547-3568.

65. Lora, J. Industrial commercial lignins: Sources, properties and applications. In Monomers, Polymers and Composites from Renewable Resources; Belgacem, M.N., Gandini, A., Eds.; Elsevier: Amsterdam, The Netherlands, 2008; pp. 225-241.

66. El Mansouri, N.E.; Salvadó, J. Structural characterization of technical lignins for the production of adhesives: Application to lignosulphonate, kraft, soda- anthraquinone, organosolv and ethanol process lignins. Ind. Crops Prod. 2006, 24, 8-16. [CrossRef]

67. Miller, J.; Faleiros, M.; Pilla, L.; Bodart, A.C. Lignin: Technology, Applications and Markets, Special Market Analysis Study; RISI, Inc., Market-Intell LCC: Charlottesville, VA, USA, 2016.

68. Ibrahim, M.N.M.; Zakaria, N.; Sipaut, C.S.; Sulaiman, O.; Hashim, R. Chemical and thermal properties of lignins from oil palm biomass as a substitute for phenol in a phenol formaldehyde resin production. Carbohydr. Polym. 2011, 86, 112-119. [CrossRef]

69. Podschun, J.; Stücker, A.; Buchholz, R.I.; Heitmann, M.; Schreiber, A.; Saake, B.; Lehnen, R. Phenolated lignins as reactive precursors in wood veneer and particleboard adhesion. Ind. Eng. Chem. Res. 2016, 55, 5231-5237. [CrossRef]

70. Hemmilä, V.; Adamopoulos, S.; Hosseinpourpia, R.; Sheikh, A.A. Ammonium lignosulfonate adhesives for particleboards with pMDI and furfuryl alcohol as cross-linkers. Polymers 2019, 11, 1633. [CrossRef] [PubMed]

71. Antov, P.; Savov, V.; Mantanis, G.I.; Neykov, N. Medium-density fibreboards bonded with phenolformaldehyde resin and calcium lignosulfonate as an eco-friendly additive. Wood Mater. Sci. Eng. 2020. [CrossRef]

72. Danielson, B.; Simonson, R. Kraft lignin in phenol formaldehyde resin. Part 1. Partial replacement of phenol by kraft lignin in phenol formaldehyde adhesives for plywood. J. Adhes. Sci. Technol. 1998, 12, 923-939. [CrossRef]

73. Kumar, R.N.; Pizzi, A. Thermosetting Adhesives Based on Bio-Resources for Lignocellulosic Composites. In Adhesives for Wood and Lignocellulosic Materials; Wiley-Scrivener Publishing: Hoboken, NJ, USA, 2019; pp. 275-277.

74. Antov, P.; Valchev, I.; Savov, V. Experimental and statistical modeling of the exploitation properties of eco-friendly MDF through variation of lignosulfonate concentration and hot pressing temperature. In Proceedings of the 2nd International Congress of Biorefinery of Lignocellulosic Materials (IWBLCM2019), Cordoba, Spain, 4-7 June 2019; pp. 104-109, ISBN 978-84-940063-7-1.

75. Savov, V.; Valchev, I.; Antov, P. Processing factors affecting the exploitation properties of environmentally friendly medium density fibreboards based on lignosulfonate adhesives. In Proceedings of the 2nd International Congress of Biorefinery of Lignocellulosic Materials (IWBLCM2019), Cordoba, Spain, 4-7 June 2019; pp. 165-169, ISBN 978-84-940063-7-1.

76. European Committee for Standardization, EN 310. Wood-Based Panels-Determination of Modulus of Elasticity in Bending and of Bending Strength; European Committee for Standardization: Brussels, Belgium, 1999.

77. European Committee for Standardization, EN 317. Particleboards and Fibreboards-Determination of Swelling in Thickness after Immersion in Water; European Committee for Standardization: Brussels, Belgium, 1998.

78. European Committee for Standardization, EN 322. Wood-Based Panels-Determination of Moisture Content; European Committee for Standardization: Brussels, Belgium, 1998.

79. European Committee for Standardization, EN 323. Wood-Based Panels-Determination of Density; European Committee for Standardization: Brussels, Belgium, 2001. 
80. European Committee for Standardization, EN ISO 12460-5. Wood-Based Panels-Determination of Formaldehyde Release-Part 5. Extraction Method (Called the Perforator Method); European Committee for Standardization: Brussels, Belgium, 2015.

81. Salem, M.Z.M.; Böhm, M. Understanding of formaldehyde emissions from solid wood: An overview. BioResources 2013, 8, 4775-4790. [CrossRef]

82. Schäfer, M.; Roffael, E. On the formaldehyde release of wood. Holz. Roh. Werkst. 2000, 58, 259-264. [CrossRef]

83. European Committee for Standardization, EN 312. Particleboards-Specifications; European Committee for Standardization: Brussels, Belgium, 2010.

84. European Committee for Standardization, EN 622-5. Fibreboards-Specifications-Part 5: Requirements for Dry Process Boards; European Committee for Standardization: Brussels, Belgium, 2010.

85. Shiag, K.; Negi, A. Physical and mechanical properties of MDF using needle punching technique. Int. J. Chem. Sci. 2017, 5, 2028-2030.

(C) 2020 by the authors. Licensee MDPI, Basel, Switzerland. This article is an open access article distributed under the terms and conditions of the Creative Commons Attribution (CC BY) license (http://creativecommons.org/licenses/by/4.0/). 